\title{
The effectiveness of pulmonary rehabilitation in connection with lung transplantation in Hungary
}

\author{
Maria Kerti ${ }^{1}$, Anikó Bohacs ${ }^{2}$, Ildiko Madurka ${ }^{3}$, Zsuzsanna Kovats ${ }^{2}$, Balazs Gieszer ${ }^{3,4}$, Jenő Elek ${ }^{3}$, \\ Ferenc Renyi-Vamos ${ }^{3,4}$, Janos Tamas Varga ${ }^{1,2}$ \\ ${ }^{1}$ Department of Pulmonary Rehabilitation, National Koranyi Institute for Pulmonology, Budapest, Hungary; ${ }^{2}$ Department of Pulmonology, \\ Semmelweis University, Budapest, Hungary; ${ }^{3}$ National Institute of Oncology, Budapest, Hungary; ${ }^{4}$ Department of Thoracic Surgery, Semmelweis \\ University, Budapest, Hungary \\ Contributions: (I) Conception and design: M Kerti, A Bohacs, I Madurka, B Gieszer, J Elek, F Renyi-Vamos, JT Varga; (II) Administrative support: \\ M Kerti, A Bohacs, Z Kovats, JT Varga; (III) Provision of study materials or patients: M Kerti, A Bohacs, Z Kovats, F Renyi-Vamos, JT Varga; (IV) \\ Collection and assembly of data: M Kerti, Z Kovats, JT Varga; (V) Data analysis and interpretation: M Kerti, A Bohacs, I Madurka, B Gieszer, J Elek, \\ F Renyi-Vamos, JT Varga; (VI) Manuscript writing: All authors; (VII) Final approval of manuscript: All authors. \\ Correspondence to: Med. habil. Janos Tamas Varga. Department of Pulmonology, Semmelweis University, No. 26 Ulloi street, H-1085 Budapest, \\ Hungary. Email: janosvargaster@gmail.com.
}

Background: The role of pre- and post-lung transplant rehabilitation is to maintain or improve exercise tolerance, lung mechanics, peripheral and respiratory muscle function. Our aim was to measure the effectiveness of pre- and post-transplant rehabilitation in terms of the changes of functional and quality of life markers.

Methods: Sixty-three patients (40 COPD FEV1: $21 \pm 5$ \% pred, 18 IPF TLC: $42 \pm 13 \%$ pred, 4 bronchiectasis FEV1: $28 \pm 4$ \% pred and 1 alveolitis fibrotisans TLC: $31 \%$ pred) participated in a pre- and 14 took part in a post-transplant rehabilitation program (more than 2 months after lung transplantation (LTx), primary diagnoses: 9 COPD, 4 IPF). The rehabilitation program consisted of chest-wall stretching, controlled breathing techniques and personalized exercise of 20-30 minutes by cycling and treadmill 2-3 times per day for 4 weeks. Seven functional and quality of life markers, like lung function, chest wall expansion (CWE), 6-minute walking distance (6MWD), modified Medical Research Council Dyspnea Scale (mMRC), COPD Assessment Test (CAT), breath holding time (BHT) and hand grip strength (HGS) were measured at the onset and the end of the rehabilitation program. The safety profile of the rehabilitation program was followed-up.

Results: Pre-transplant pulmonary rehabilitation resulted in significant improvement in CWE $(3.24 \pm 1.49$ vs. $4.48 \pm 1.62 \mathrm{~cm})$, CAT IQR $\{19$ [13-25] vs. 15 [11-21]\}, 6MWD $(315 \pm 118$ vs. $375 \pm 114 \mathrm{~m}), \mathrm{P}<0.05$. FEV1, FVC, mMRC, BHT and HGS did not change significantly. Post-transplant rehabilitation resulted in significant improvement in CWE $(3.7 \pm 2.1$ vs. $6.2 \pm 1.8 \mathrm{~cm})$, CAT IQR $\{17$ [11-23] vs. 10 [6-14], BHT $(22 \pm 14$ vs. $35 \pm 16$ s), FEV1 (73 \pm 8 vs. $86 \pm 9 \%$ pred) and FVC ( $70 \pm 12$ vs. $85 \pm 14 \%$ pred), $\mathrm{P}<0.05$. The 6 MWD, mMRC and HGS did not change significantly. No cardiovascular or other side effects were detected during the rehabilitation program.

Conclusions: Our results underline the importance of perioperative pulmonary rehabilitation in the complex treatment of lung transplant patients in Hungary, as well. There was a limitation because no control group was evaluated without rehabilitation.

Keywords: Pulmonary rehabilitation; lung transplantation (LTx); exercise capacity; quality of life; physical activity, peripheral and respiratory muscle function

Submitted Sep 05, 2020. Accepted for publication Jan 15, 2021.

doi: 10.21037/apm-20-1783

View this article at: http://dx.doi.org/10.21037/apm-20-1783 


\section{Introduction}

Lung transplantation (LTx) is an optional treatment for patients in end-stage chronic lung diseases, when life expectancy of these patients is higher with this intervention than without it (1). The number of LTx has been increasing, and the survival rate is significantly longer compared to 10 20 years ago (2). Candidates for LTx have severe symptoms caused by different chronic pulmonary diseases, they have significant medical comorbidities, ventilatory limitation, exercise intolerance and inactivity in daily life (3). Reduction in quality of life (QoL), dysfunction of diaphragm and peripheral muscles appear in patients waiting for $\operatorname{LTx}(4,5)$. There is a question about the timing of pre-, early- and late post-transplant rehabilitation and the exercise training modality to improve quality of life. The indications of LTx can be different chronic respiratory diseases with respiratory failure such as Chronic Obstructive Pulmonary Disease (COPD), Interstitial Lung Disease (ILD), Bronchiectasis, Cystic Fibrosis (CF) and pulmonary arterial hypertension (PAH) (2). Pulmonary rehabilitation is a safe treatment of patients with chronic lung diseases, preparing for LTx and recovering from transplant surgery (6). There is question about the relationship of LTx pre-transplant modification of muscle's function and improved clinical outcomes after transplant. Pulmonary rehabilitation for LTx candidates can help to optimize the functional status, it can improve their exercise tolerance. After $\mathrm{Tx}$ intervention it can help to recover the muscle function of both peripheral and inspiratory muscles and to enhance their exercise tolerance (6). Muscle weakness and inactivity can be highly frequent in candidates for transplantation and recipients after surgery $(7,8)$. Comorbidities such as hypertension, diabetes, atherosclerosis and secondary PAH can be detected in chronic respiratory diseases $(9,10)$. Despite nearly normal lung function in lung transplant recipients, muscle strength is decreased after surgery due to long intensive care unit (ICU) treatment (7). The rehabilitation program can improve exercise capacity, muscle function and quality of life both before and after LTx (11).

There is a question about the relative effectiveness of the pre- and post-transplant rehabilitation program and which elements of the transplant rehabilitation program potentiate the effectiveness. We present the following article in accordance with the STROBE reporting checklist (available at http://dx.doi.org/10.21037/apm-20-1783).

\section{Methods}

\section{Participants}

Sixty-three candidates for LTx and 14 recipients participated in this study from 2012 to 2019. Forty COPD $\left(\mathrm{FEV}_{1}: 21 \pm 5 \%\right.$ pred), 18 IPF (TLC: $42 \pm 13 \%$ pred), 4 bronchiectasis $\left(\mathrm{FEV}_{1}: 28 \pm 4 \%\right.$ pred) patients and one patient with alveolitis fibrotisans (TLC: $31 \%$ pred) participated in the pre-transplant rehabilitation group (see demographics in Table 1). Fourteen individuals took part in a post-transplant rehabilitation program (primary diagnoses: 9 COPD, 4 IPF) (see demographics in Table 1). Inclusion criteria was based on the selection of lung transplant candidates int the ASTP/ATS/ERS/ISHLT guideline (12). Exclusion criteria was not compliance in the pulmonary rehabilitation program including severe psychological disorder, severe joint disease, NYHA IV heart failure and ischemic heart disease, which needed an intervention (12). The program was performed at the Department of Pulmonary Rehabilitation, National Koranyi Institute for Pulmonology, Budapest, Hungary. All patients were fully anonymized. The study was conducted in accordance with the Declaration of Helsinki (as revised in 2013). The study was approved by institutional ethics committee of No $25 / 2017$ and informed consent was taken from all individual participants. The study was registered at ISRCTN registry with ISRCTN13019180 ID.

\section{Statistical methods}

Descriptive statistics was created (average, $\mathrm{SD} \pm$ ), normal distribution was tested by Kolmogorov-Smirnov test. $T$-test for continuous variables following normal distribution and Mann-Whitney test for continuous variables not following normal distribution was performed. FPs were checked before and after rehabilitation, the change of parameters was statistically analyzed, the significance of change was checked by paired $t$-test. Significance level was set at $\mathrm{P}<0.05$, using Wilcoxon Signed test. Scatterplot distribution was analyzed.

\section{Intervention}

\section{Rehabilitation program}

The patients underwent a complex pulmonary rehabilitation (PR) program: controlled breathing technics, chest wall 
Table 1 Patient demographic characteristics

\begin{tabular}{lcc}
\hline Patient characteristics & Pre-transplant group & Post-transplant group \\
\hline Number & $\mathrm{n}=63$ & $\mathrm{n}=14$ \\
Male/female & $34 / 29$ & $11 / 3$ \\
Age & $58 \pm 6.6$ & $52 \pm 8.8$ \\
BMl $\left(\mathrm{kg} / \mathrm{m}^{2}\right)$ & $2.6 \pm 5.4$ & $22.5 \pm 2.8$ \\
FVC $(\%$ pred) & $54 \pm 14$ & $71 \pm 12$ \\
FEV $(\%$ pred) & $29 \pm 16$ & $73 \pm 8$ \\
Hypertension & $42(67 \%)$ & $8(57 \%)$ \\
Diabetes & $15(24 \%)$ & $3(21 \%)$ \\
Pulmonary hypertension & $20(32 \%)$ & $4(29 \%)$ \\
Atherosclerosis & $44(70 \%)$ & $8(57 \%)$ \\
\hline
\end{tabular}

Table 2 Follow-up of functional parameters

Chest wall expansion (CWE)

Maximal inspiratory pressure (MIP)

FEV $_{1} \%$ pred

FVC\%pred (forced vital capacity)

IVC(L) (inspiratory vital capacity)

IVC\%pred (inspiratory vital capacity)

6 minutes walking distance (6MWD)

Hand grip strength (HGS)

Breath-holding time (BHT)

mMRC (Modified Medical Research Council Dyspnea Scale)

CAT (COPD Assessment Test)

BODE-index

Alternative-scale (AS)

stretching and chest mobility improving technics as well as muscle force developing training in groups every day for 30 minutes; a personalized exercise training on bicycle or treadmill 2-3 times per day for 15-20 minutes, in continuous or interval form, for 4 weeks.

Breathing exercises were performed in an open-air corridor to take advantage of the special microclimate of our institute. The advantage of group exercise is that patients encourage and motivate each other. Patients learned and performed controlled breathing techniques, muscle strengthening-, stretching- and chest-spine mobilization techniques $(13,14)$. The force of diaphragm can be decreased in chronic pulmonary diseases, so improving the diaphragm function is very important (15).

The personalized and supervised exercise training was set up according to the patients' symptoms based on BORG score (both dyspnea and leg fatigue). The intensity and duration were increased until reaching grade 7 , according to the international guidelines (13).

Patients were controlled by physiotherapists, monitoring saturation and heart rate (16). The actual status, blood gas values and comorbidities were considered to ensure the individual training form. The exercise training performed by our patients was a high intensity continuous (C) or interval training (IT) (17-20). COPD is in close relationship with smoking, so we paid attention to smoking cessation with supervised education 2-3 times a week. Smoking cessation program is considered to prevent different complications in patients who undergo thoracic surgery (21).

The changes of different functional parameters were assessed from PR admission to discharge (Table 2). The evaluated parameters were lung function test $\left(\mathrm{FEV}_{1}, \mathrm{FVC}\right)$, 6-minute walking distance (6MWD), chest wall expansion (CWE), maximal inspiratory pressure (MIP), breath holding time (BHT) and hand grip strength (HGS). The quality of life was assessed by CAT (COPD Assessment Test) and the degree of dyspnea by mMRC (Modified Medical Research Council Dyspnoe Scale). The BODE-index and a newly created Alternative Scale were used to evaluate the severity of COPD (Table 2). 


\section{Outcomes}

\section{Measurements}

The following functional parameters were measured before and after rehabilitation program (Table 2).

\section{Pulmonary function}

All patients underwent post-bronchodilator pulmonary function test $\left(\mathrm{V}_{\max } 229\right.$ and Autobox 6200; Sensormedics, Yorba Linda, CA, USA) including spirometry measurements (22) according to the American Thoracic Society/European Respiratory Society guidelines. Patients with COPD inhaled 400 microgram of salbutamol 20 minutes before lung function. Dynamic spirometry values, $\mathrm{FEV}_{1}$, FVC, airway obstruction $\left(\mathrm{FEV}_{1} / \mathrm{FVC}\right)$ and resting slow vital capacity (VC) were measured with this test.

\section{MWT}

The $6 \mathrm{MWT}$ is widely used to evaluate the exercise capacity of patients with chronic lung diseases. It correlates strongly with peak work rate and physical activity (23). It was measured in the corridor of our department, the individuals were asked to walk as fast as possible, they were encouraged often during the test. Oxygen saturation and heart rate were evaluated before, during and after the test, dyspnea and leg fatigue were assessed by the modified BORG-scale, according to the international guideline $(24,25)$.

\section{CWE}

Chest wall expansion was measured at the level of xyphoid process with centimeter band between maximal inhalation and exhalation. The maneuver was repeated three times, and the average of the three results was evaluated (26).

\section{MIP}

We used the special digital instrument named POWERbreathe Kh1 (POWERbreathe International Limited, Southam, UK) to measure maximal pressures of the respiratory muscles. The results were calculated based on the patients' height, weight, gender and age, and were classified as "very poor", "poor", "fair", "average", "good" "very good". The individuals were asked to exhale maximally and inhale suddenly with a maximal force in a short time (27). The measurements were repeated three times and the average of three obtained values was calculated.

\section{BHT}

The breath holding test gives us much information about the onset and endurance of dyspnea (28). The patients were asked to hold their breath for as long as possible. The nose and mouth were closed (29).

\section{HGS}

It was measured by a special electric handgrip dynamometer (2016 Kern and Sohn GmbH, Balingen, Germany). The test was repeated three times, and the average of the three values was calculated $(30,31)$.

\section{Quality of life and dyspnoe score}

Health status was evaluated by CAT test (32), and dyspnea was screened using mMRC dyspnoe scale (33).

\section{Bode-index, Alternative Scale}

We used the BODE-index (based on BMI, FEV ${ }_{1}, \mathrm{mMRC}$ score and 6MWD) and the newly created Alternative-scale (based on BMI, $\mathrm{FEV}_{1}$, CAT score and 6MWD) to evaluate 169the severity of the COPD (9,34).

\section{Safety profile}

The during the rehabilitation training program we followed the vital signs (blood pressure, pulse, saturation) of the patients and regularly we performed ECG for the patients. We asked the symptoms of the patients and if it was needed, we did laboratory or chest X-ray based on the posttransplant protocol.

\section{Results}

The demographics, lung function and co-morbidities of the patients are presented in Table 1. The selection of the patients was based on the inclusion criteria of LTx. The physical activity and muscle strength were very low in almost all of the patients, so they needed to participate in a rehabilitation program as candidates and after LTx. Comorbidities were similar compared to international data in this population. The rehabilitation resulted in significant improvement in chest mobility, quality of life and exercise tolerance in LTx candidates (Table 3), otherwise the following functional parameters did not change significantly: $\mathrm{FEV}_{1} \%$ pred, FVC\% pred, mMRC, BHT and HGS (Table 3). The severity of COPD decreased in Pre-transplant group (BODE-index and the newly created Alternative Scale - AS), but the difference was not significant (Table 3).

The rehabilitation program resulted significant changes in CWE, CAT, BHT, FEV ${ }_{1} \%$ pred and FVC\% pred $(\mathrm{P}<0.05)$ after LTx (Table 4). 6MWD, mMRC and HGS did not change significantly in this group (Table 4). Our results display that the pulmonary rehabilitation program can help to maintain or improve chest mobility, quality of life and exercise tolerance both in $\mathrm{Tx}$ candidates and recipients as well (Tables 3,4). The pulmonary rehabilitation program was supervised and personalized, we asked a cardiologist for his 
Table 3 The changes of functional parameters in pre-transplant group

\begin{tabular}{lccc}
\hline Functional parameters & Before rehabilitation & After rehabilitation & Significance level \\
\hline CWE $(\mathrm{cm})$ & $3.24 \pm 1.49$ & $4.48 \pm 1.62$ & $\mathrm{P}<0.05$ \\
MIP $\left(\mathrm{cmH}_{2} \mathrm{O}\right)$ & $40 \pm 15$ & $44 \pm 17$ & n.s. \\
FEV $(\%$ pred $)$ & $29 \pm 16$ & $30 \pm 13$ & n.s. \\
FVC (\%pred) & $54 \pm 13$ & $57 \pm 14$ & n.s. \\
IVC (L) & $1.96 \pm 0.6$ & $2.1 \pm 0.7$ & n.s. \\
IVC (\%pred) & $55 \pm 13$ & $59 \pm 14$ & n.s. \\
6MWD (m) & $315 \pm 118$ & $375 \pm 114$ & P<0.05 \\
HGS (kg) & $27.1 \pm 8.1$ & $29.2 \pm 7.9$ & n.s. \\
BHT (s) & $22.6 \pm 9.2$ & $26.3 \pm 10.6$ & n.s. \\
mMRC IQR & $2.3(1.6-3.0)$ & $1.9(1.1-2.7)$ & n.s. \\
CAT IQR & $19[13-25]$ & $15[9-21]$ & P<0.05 \\
BODE-index IQR & $5.4(3.9-7.1)$ & $4.4(2.9-5.9)$ & n.s. \\
AS IQR & $5.6(4.2-7.0)$ & $4.6(3.4-5.8)$ & n.s. \\
\hline
\end{tabular}

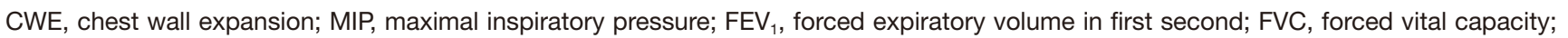
IVC, inspiratory vital capacity; 6MWD, 6-minute walking distance; HGS, hand grip strength; BHT, breath holding time; mMRC, modified Medical Research Council Dyspnea Scale; CAT, COPD Assessment Test; AS, Alternative Scale.

Table 4 The changes of functional parameters in post-transplant group

\begin{tabular}{lccc}
\hline Functional parameters & Before rehabilitation & After rehabilitation & Significance level \\
\hline CWE (cm) & $3.7 \pm 2.1$ & $6.2 \pm 1.8$ & $\mathrm{P}<0.05$ \\
FEV $(\%$ pred) & $73 \pm 8$ & $86 \pm 9$ & $\mathrm{P}<0.05$ \\
FVC (\%pred) & $70 \pm 12$ & $85 \pm 14$ & $\mathrm{P}<0.05$ \\
6MWD (m) & $303 \pm 124$ & $407 \pm 120$ & $\mathrm{n} . \mathrm{s}$. \\
HGS (kg) & $21.1 \pm 7,1$ & $25.2 \pm 4$ & $\mathrm{n} . \mathrm{s}$. \\
BHT (s) & $22 \pm 14$ & $36 \pm 16$ & $\mathrm{P}<0.05$ \\
mMRC IQR & $1.7(0.6-2.8)$ & $0.8(0.4-1.2)$ & $\mathrm{n} . \mathrm{s}$. \\
CAT IQR & $17[11-23]$ & $10[6-14]$ & $\mathrm{P}<0.05$ \\
\hline
\end{tabular}

CWE, chest wall expansion; $\mathrm{FEV}_{1}$, forced expiratory volume in first second; FVC, forced vital capacity; 6MWD, 6-minute walking distance; HGS, hand grip strength; BHT, breath holding time; mMRC, modified Medical Research Council Dyspnea Scale; CAT, COPD Assessment Test.

opinion if it was necessary. We did not detect cardiovascular or any other side effects during the training period.

\section{Discussion}

We analyzed the effect of pulmonary rehabilitation in LTx candidates and recipients in this study. LTx is a potential treatment of end-stage severe pulmonary diseases such as COPD, ILD, Bronchiectasis, CF and PAH. We have to choose individual, closely controlled and supervised training programs for our patients, based on the different comorbidities and side effects of the advanced chronic respiratory diseases (PAH, dynamic hyperinflation) and permanent chronic inflammation (35-40). Nutritional and functional status are impaired, and low physical activity levels can be detected in advanced pulmonary diseases 
$(41,42)$. The pulmonary rehabilitation program can improve these factors in perioperative cases with chronic respiratory failure both pre- and post LTx (10,43-46).

\section{Rehabilitation before LTx}

Pulmonary rehabilitation can help to maintain or improve the patients' physical activity and quality of life before chest surgery and lung- or heart-LTx. Langer et al. investigated exercise tolerance $(6 \mathrm{MWD})$, quadriceps force $(\mathrm{QF})$, walking time and physical activity before and after transplantation (immediately, 3 months and 1 year after). These parameters did not change significantly immediately after LTx, but they improved significantly in 3 months and 1 year (11). Thirty-six patients were observed before and after LTx with rehabilitation by Maury et al. The measured parameters were $\mathrm{FEV}_{1}, 6 \mathrm{MWD}, \mathrm{QF}$ and HGS. FEV ${ }_{1}$ improved significantly after surgery, and it showed further improvement after rehabilitation. 6MWD did not change significantly after surgery, but it improved significantly after rehabilitation. QF and HGS decreased after transplantation and improved after the rehabilitation phase. We found similar results in impaired exercise tolerance, HGS in the pre-transplant group in our study. 6MWD did not change significantly in the post-transplant group, $\mathrm{FEV}_{1} \%$ pred, $\mathrm{FVC} \%$ pred, quality of life, chest mobility and BHT improved significantly in more than 2 months after surgery (7).

Li et al. evaluated 345 pre-Tx patients in a pulmonary rehabilitation program. The examined parameters were 6MWD, health related quality of life (HRQL) and exercise training volumes. They observed decreased functional parameters in candidates for Tx. Patients with greater exercise capacity had a more favorable post-Tx outcome (47).

Schwaiblmair et al. analyzed the cardiopulmonary exercise test parameters of 103 recipients (single lung Tx: $\mathrm{n}=46$, double lung Tx: $\mathrm{n}=32$ and heart-lung $T \mathrm{x}: \mathrm{n}=25$ ) before and shortly after Tx. Impaired functional parameters (work capacity, predicted oxygen uptake and predicted oxygen pulse) were found in patients before surgery. Peak of oxygen uptake increased after Tx, patients reached the maximum oxygen uptake in 2 months after Tx (48). Reduced functional parameters were found in individuals waiting for LTx in our study, too. The rehabilitation program can help to improve these functional factors for surgery. Our study showed significant improvement in chest wall expansion, exercise capacity and quality of life.

\section{Rehabilitation after transplantation}

LTx recipients have reduced exercise capacity despite a nearly normal pulmonary function, which is related to complex and severe pre- and postoperative factors. After LTx or HLTx, the breathing pattern and chemo sensitivity are altered $(49,50)$. Hemodynamic response and skeletal muscle oxidative capacity are abnormal. Ross et al. evaluated $8 \mathrm{LT}$ recipients before and after Tx. The patients performed an incremental cycling test. The $\mathrm{VO}_{2 \max }$ increased after $v s$. before LT. After transplantation the thresholds were abnormally low $(35 \% \pm 3 \%)$, an early rise of arterial lactate was detected, and the stroke volume index was higher. They concluded that pulmonary vascular failures are manifested in the majority of LT recipients. Evans et al. examined 9 patients after Tx compared to 8 healthy individuals. The patients underwent an incremental exercise test to exhaustion. Pulmonary gas exchange, minute ventilation, blood lactate and quadriceps $\mathrm{pH}$ were measured. Decreased $\mathrm{VO}_{2 \max }$ and lower metabolic rate were observed, the quadriceps $\mathrm{pH}$ in rest was more acidotic in the Tx-group (51,52). We evaluated these parameters by incremental cycling test occasionally, we plan to measure these parameters in our clinical practice in the future in general.

Many studies reported both respiratory and skeletal muscles dysfunction after lung- and heart-lung Tx. Ambrosino et al. conducted a study on 11 heart-lung Tx patients and followed them for 18 months. Every 6 months the patients underwent different tests: incremental treadmill exercise, $6 \mathrm{MWD}$, MIP, maximal expiratory pressure (MEP), isokinetic contraction of leg flexor and extensor (IFX, IEX) examinations. The $\mathrm{VO}_{2}$ peak and the function of respiratory and skeletal muscles improved further in 6 and 12 months after HLTx, but it still remained lower than physiologic values after 18 months (53).

Pantoja et al. compared 9 LTx recipients to age- and sex-matched healthy individuals. MIP, MEP and strength of ankle dorsiflexor were measured. Significantly reduced values were found in MEP and strength of dorsiflexor in patient after Tx. MIP was non-significantly impaired. They concluded that the weakness of respiratory- and peripheral muscles can contribute to exercise intolerance in $\mathrm{Tx}$ recipients (54). We also evaluated the respiratory muscle(MIP) and peripheral muscle functions (HGS) in our study. These values were impaired in our patients, too.

Dynamic hyperinflation in end-stage COPD is 
frequently manifested in reduced exercise tolerance, physical activity and impaired quality of life. The anatomic position and function of the diaphragm is altered (9). Wanke et al. supposed that the function of diaphragm is altered in COPD patients who underwent LTx because the severe disease persisted for a long time, and special changes were found in the diaphragmatic structure due to dynamic hyperinflation. They investigated 14 patients after Tx, lung volume and trans-diaphragmatic pressure were measured. They found that dynamic hyperinflation did not inflict functional changes in diaphragm after surgery (55). We investigated the function of diaphragm and MIP in patients with COPD, who had dynamic hyperinflation in an earlier study. Their quality of life and exercise tolerance were significantly reduced. The rehabilitation program resulted in significant improvement in chest movement, quality of life, exercise tolerance and muscle function.

Impaired physical fitness is reported in patients after LTx. It can be caused by prolonged ICU treatment in the early phase after Tx $(56,57)$. Physical activity may be reduced in different phases after LTx. Langer et al. reported decreased daily life activity level in patients 1 year after Tx compared to sex- and age-matched healthy patients. The number of daily steps, standing time, daily activity, $6 \mathrm{MWD}$ and QoL were measured, and all of these parameters were lower in Tx recipients than in healthy individuals (58). Langer subsequently investigated the effect of a 3-month exercise training in LTx patients immediately after surgery and compared them to a control group without intervention. The patients were followed for a year, daily walking time (in minutes), QF, physical fitness and cardiovascular morbidity were measured. The daily walking time was higher (85 \pm 27 vs. $54 \pm 30 \mathrm{~min}), \mathrm{QF}, 6 \mathrm{MWD}$ and self-reported physical functioning significantly improved in the training group (59).

The Whole-Body Vibration Training may be an optional treatment in pulmonary rehabilitation for patients with COPD. Gloeckl et al. evaluated this training mode in LT recipients, as well. Eighty-three individuals participated in this study in two groups (WBVT-group $308 n=34$, CONgroup $n=36$ ). Both groups underwent a complex pulmonary rehabilitation program, the patients in WBVT-group performed $4 \times 2$-minute training on a vibration platform. The $6 \mathrm{MWD}$ and peak work rate increased significantly in the WBVT-group compared with the CON-group (60). We used WBV training in patients with COPD and LTx recipients, but we have not analyzed the results of this training yet.
Andrianopoulos et al. assessed the improvement in functional and cognitive status in COPD transplant recipients. Significant improvements were found both in functional parameters (6MWD, diffusion capacity) and cognitive parameters (learning skills, memory ability) as an effect of pulmonary rehabilitation in patients after LTx (61). We also investigated the functional factors in our rehabilitation program. Similar results were found in our study in evaluated parameters after transplantation.

Our study has some limitations. We did not measure the physiologic parameters of the exercise in general, we are planning to follow-up these parameters in the process of LT. As a potential aim we can focus on more functional parameters to evaluate the functional condition of these patients. Higher percentage of LT recipients need to be involved in the post-LT rehabilitation program.

In conclusion, we performed a PR program in pretransplant patients and LT recipients. Pre-transplant pulmonary rehabilitation resulted in significant improvement in CWE, CAT and $6 \mathrm{MWD}^{\mathrm{FEV}} \mathrm{FEV}_{1}, \mathrm{FVC}$ mMRC, BHT and HGS did not change significantly. Post-transplant rehabilitation resulted in significant improvement in CWE, CAT, BHT, $\mathrm{FEV}_{1}$, and FVC. The 6MWD, mMRC and HGS did not change significantly. The study can help for pulmonary rehabilitation specialists to generalize the transplant rehabilitation.

\section{Acknowledgments}

The authors would like to thank physiotherapists Zsuzsanna Balogh and Beatrix Bayer and psychologists Zsofia Hodovan and Erzsebet Ritterodesz working in the rehabilitation team.

Funding: None.

\section{Footnote}

Reporting Checklist: The authors have completed the STROBE reporting checklist. Available at http://dx.doi. org/10.21037/apm-20-1783

Data Sharing Statement: Available at http://dx.doi. org/10.21037/apm-20-1783

Conflicts of Interest: All authors have completed the ICMJE uniform disclosure form (available at http://dx.doi. org/10.21037/apm-20-1783). The authors have no conflicts of interest to declare. 
Ethical Statement: The authors are accountable for all aspects of the work in ensuring that questions related to the accuracy or integrity of any part of the work are appropriately investigated and resolved. The study was conducted in accordance with the Declaration of Helsinki (as revised in 2013). The study was approved by institutional ethics committee of No. 25/2017 and informed consent was taken from all individual participants.

Open Access Statement: This is an Open Access article distributed in accordance with the Creative Commons Attribution-NonCommercial-NoDerivs 4.0 International License (CC BY-NC-ND 4.0), which permits the noncommercial replication and distribution of the article with the strict proviso that no changes or edits are made and the original work is properly cited (including links to both the formal publication through the relevant DOI and the license). See: https://creativecommons.org/licenses/by-nc-nd/4.0/.

\section{References}

1. Lahzami S, Bridevaux PO, Soccal PM, et al. Survival impact of lung transplantation for COPD. Eur Respir J 2010;36:74-80.

2. Chambers DC, Yusen RD, Cherikh WS, et al. The Registry of the International Society for Heart and Lung Transplantation: Thirty-fourth Adult Lung And HeartLung Transplantation Report-2017; Focus Theme: Allograft ischemic time. J Heart Lung Transplant 2017;36:1047-59.

3. Rochester CL. Pulmonary rehabilitation for patients who undergo lung-volume-reduction surgery or lung transplantation. Respir Care 2008;53:1196-202.

4. Wickerson L, Rozenberg D, Janaudis-Ferreira T, et al. Physical rehabilitation for lung transplant candidates and recipients: An evidence-informed clinical approach. World J Transplant 2016;6:517-31.

5. Rozenberg D, Singer LG, Herridge M, et al. Evaluation of Skeletal Muscle Function in Lung Transplant Candidates. Transplantation 2017;101:2183-91.

6. Spruit MA, Singh SJ, Garvey C, et al. An official American Thoracic Society/European Respiratory Society statement: key concepts and advances in pulmonary rehabilitation. Am J Respir Crit Care Med 2013;188:e13.

7. Maury G, Langer D, Verleden G, et al. Skeletal muscle force and functional exercise tolerance before and after lung transplantation: a cohort study. Am J Transplant 2008;8:1275-81.
8. Langer D, Cebrià i Iranzo MA, Burtin C, et al. Determinants of physical activity in daily life in candidates for lung transplantation. Respir Med 2012;106:747-54.

9. Kerti M, Balogh Z, Kelemen K, et al. The relationship between exercise capacity and different functional markers in pulmonary rehabilitation for COPD. Int J Chron Obstruct Pulmon Dis 2018;13:717-24.

10. Vagvolgyi A, Rozgonyi Z, Kerti M, et al. Effectiveness of pulmonary rehabilitation and correlations in between functional parameters, extent of thoracic surgery and severity of post-operative complications: randomized clinical trial. J Thorac Dis 2018;10:3519-31.

11. Langer D. Rehabilitation in Patients before and after Lung Transplantation. Respiration 2015;89:353-62.

12. International guidelines for the selection of lung transplant candidates. The American Society for Transplant Physicians (ASTP)/American Thoracic Society(ATS)/ European Respiratory Society(ERS)/International Society for Heart and Lung Transplantation(ISHLT). Am J Respir Crit Care Med 1998;158:335-9.

13. Rochester CL, Vogiatzis I, Holland AE, et al. ATS/ERS Task Force on Policy in Pulmonary Rehabilitation. An official American Thoracic Society/European Respiratory Society Policy Statement: enhancing implementation, use and delivery of pulmonary rehabilitation. Am J Respir Crit Care Med 2015;192:1373-86.

14. de Sá RB, Pessoa MF, Cavalcanti AGL, et al. Immediate effects of respiratory muscle stretching on chest wall kinematics and electromyography in COPD patients. Respir Physiol Neurobiol 2017;242:1-7.

15. Charususin N, Gosselink R, Decramer M, et al. Inspiratory muscle training protocol for patients with chronic obstructive pulmonary disease (IMTCO study): a multicentre randomised controlled trial. BMJ Open 2013;3:e03101.

16. Varga J, Boda K, Somfay A. The effect of controlled and uncontrolled dynamic lower extremity training in the rehabilitation of patients with chronic obstructive pulmonary disease. Orv Hetil 2005;146:2249-55.

17. Varga J, Porszasz J, Boda K, et al. Supervised high intensity continuous and interval training vs. self-paced training in COPD. Respir Med 2007;101:2297-304.

18. Gloeckl R, Halle M, Kenn K. Interval versus Continous Training in Lung Tannsplant Candidates: A Randomized Trial. J Heart Lung Transplant 2012;31:934-41.

19. Böszörményi N Gy, Balikó Z, Kovács G, et al. Egészségügyi szakmai irányelv a krónikus obstruktív tüdőbetegség (COPD) diagnosztikájáról és kezeléséröl, az 
alap-, a szak- és a sürgősségi ellátás területén. Medicina Thoracalis (Budapest) 2014:67:76-112.

20. Varga J, Porszasz J, Boda K, et al. Felügyelt magas intenzitású folyamatos és intervallum, valamint otthoni tréning hatásának vizsgálata krónikus obstruktív tüdőbetegek rehabilitációjában. Medicina Thoracalis (Budapest) 2008;61:135-43.

21. Varga JT. Smoking and pulmonary complications: respiratory prehabilitation. J Thorac Dis 2019;11:S639-44.

22. Quanjer PH, Tammeling GJ, Cotes JE, et al. Lung volumes and forced ventilatory flows. Report Working Party Standardization of Lung Function Tests, European Community for Steel and Coal. Official Statement of the European Respiratory Society. Eur Respir J Suppl 1993;16:5-40.

23. Singh SJ, Puhan MA, Andrianopoulos V, et al. An official systematic review of the European Respiratory Society/ American Thoracic Society: measurement properties of field walking tests in chronic respiratory disease. Eur Respir J 2014;44:1447-78.

24. Balke B. A simple field test for assessment of physical fitness. Rep Civ Aeromed Res Inst US 1963:1-8.

25. Holland AE, Spruit MA, Troosters T, et al. An official European Respiratory Society/American Thoracic Society technical standard: field walking tests in chronic respiratory disease. Eur Respir J 2014;44:1428-46.

26. Debouche S, Pitance L, Robert A, et al. Reliability and reproducibility of chest wall expansion measurement in young healthy adults. J Manipulative Physiol Ther 2016;39:443-9.

27. American Thoracic Society / European Respiratory Society. ATS/ERS Statement on respiratory muscle testing. Am J Respir Crit Care Med 2002;166:518-624.

28. Nishino T. Pathophysiology of Dyspnea Evaluated by Breath-Holding Test: Studies of Furosemide Treatment. Respir Physiol Neurobiol 2009;167;20-5.

29. Mirsky IA, Liistro E, Grinker RR. Breath holding time in anxiety states. Fed Proc 1946;5:74.

30. Jeong M, Kang HK, Song P, et al. Hand grip strength in patients with chronic obstructive pulmonary disease. Int J Chron Obstruct Pulmon Dis 2017;12:2385-90.

31. An KN, Chao NY, Askew LJ. Hand strength measurements. Arch Phys Med Rehabil 1980;61:366-8.

32. Jones PW, Tabberer M, Chen WH. Creating scenarios of the impact of COPD and their relationship to COPD Assessment Test $\left(\mathrm{CAT}^{\mathrm{TM}}\right)$ scores. BMC Pulm Med 2011;11:42.

33. Launois C, Barbe C, Bertin E, et al. The modified Medical
Research Council scale for the assessment of dyspnea in daily living in obesity: a pilot study. BMC Pulm Med 2012;12:61.

34. Cote CG, Celli BR. Pulmonary rehabilitation and BODE index in COPD. Eur Respir J 2005;26:630-6.

35. Varga J, Palinkas A, Lajko I, et al. Pulmonary Arterial Pressure Response During Exercise in COPD: A Correlation with C-Reactive Protein (hsCRP). Open Respir Med J 2016;10:1-11.

36. Varga J, Casaburi R, Ma S, et al. Relation of Concavity in the Expiratory Flow-Volume Loop to Dynamic Hyperinflation During Exercise in COPD. Respir Physiol Neurobiol 2016;234:79-84.

37. Márton J, Farkas G, Nagy Z, et al. Plasma Levels of TNF and IL-6 Following Induction of Acute Pancreatitis and Pentoxifylline Treatment in Rats. Acta Chir Hung 1997:36:223-5.

38. Varga J, Szilasi M. A pulmonológiai rehabilitáció kézikönyve. SpringMed, Budapest, 2018.

39. Hegedüs B, Varga J, Somfay A. Interdisplinary rehabilitation in patients with Ankylosing Spondylitis. Orv Hetil 2016;157:1126-32.

40. Kerti M, Balogh Z, Varga J. Új eszközök a pulmonológiai fizikotherápiában. Med Thor 2015;68:200-5.

41. Fekete M, Pongor V. Fehér Á, et al. Relationship of chronic obstructive pulmonary disease and nutritional status - clinical observations. Hungarian Medical Journal 2019;160:908-13.

42. Wickerson L, Mathur S, Helm D, et al. Physical Activity Profile of Lung Transplant Candidates With Interstitial Lung Disease. J Cardiopulm Rehabil Prev 2013;33:106-12.

43. Pako J, Barta I, Balogh ZS, et al. Assessment of AntiAging Klotho Protein in Patients with COPD Underoing Pulmonary Rehabilitation. COPD 2017;14:176-80.

44. Kerti M, Balogh ZS, Varga J. New devices in pulmonology physiotherapy. Medicina Thoracalis (Budapest) 2015:68:200-5.

45. Bartels MN, Armstrong HF, Gerardo RE, et al. Evaluation of Pulmonary Function and Exercise Performance by Cardiopulmonary Exercise Testing Before and After Lung Transplantation. Chest 2011;140:1604-11.

46. Vagvolgyi A, Rozgonyi Zs, Vadász P, et al. A mellkassebészeti műtéti teherbíróképesség megítélése, perioperatív légzésrehabilitáció. Orvosi Hetilap 2017;158:1989-97.

47. Li M, Mathur S, Chowdhung NA, et al. Pulmonary rehabilitation in lung transplant candidates. J Heart Lung Transplant 2013;32:626-32. 
48. Schwaiblmair M, Reichenspurner H, Müller C, et al. Cardiopulmonary Exercise Testing Before and After Lung and Heart-Lung Transplantation. Am J Respir Crit Care Med 1999;159:1277-83.

49. Sanders MH, Owens GR, Sciurba FC, et al. Ventilation and Breathing Pattern during Progressive Hypercapnia and Hypoxia after Human Heart-Lung Transplantation. Am Rev Respir Dis 1989;140:38-44.

50. Sciurba FC, Owens GR, Sanders MH, et al. Evidence of an altered pattern of breathing, during exercise in recipients of heart-lung transplants. $\mathrm{N}$ Engl J Med 1988;319:1186-92.

51. Ross DJ, Waters PF, Mohsenifar Z, et al. Hemodynamic Responses to Exercise After Lung Transplantation. Chest 1993;103:46-53.

52. Evans AB, Al-Himyary AJ, Hrovat MI, et al. Abnormal skeletal muscle oxidative capacity after lung transplantation by 31P-MRS. Am J Respir Crit Care Med 1997;155:615-21.

53. Ambrosino N, Bruschi C, Callegari G, et al. Time course of exercise capacity, skeletal and respiratory muscle performance after heart-lung transplantation. Eur Respir J 1996;9:1508-14.

54. Pantoja JG, Andrade FH, Stoki DS, et al. Respiratory and Limb Muscle Function in Lung Allograft Recipients. Am J Respir Crit Care Med 1999;160:1205-11.

55. Wanke T, Merkle M, Formanek D, et al. Effect of lung

Cite this article as: Kerti M, Bohacs A, Madurka I, Kovats Z, Gieszer B, Elek J, Renyi-Vamos F, Varga JT. The effectiveness of pulmonary rehabilitation in connection with lung transplantation in Hungary. Ann Palliat Med 2021;10(4):3906-3915. doi: 10.21037/apm-20-1783 transplantation on diaphragmatic funktion in patients with chronic obstructive pulmonary disease. Thorax 1994;49:459-64.

56. Truong AD, FanE, Brower RG, et al. Bench-to-bedside review: mobilizing patients in the intensive care unit - from pathophysiology to clinical trials. Crit Care 2009;13:216.

57. De Jonghe B, Sharshar T, Lefaucheur JP, et al. Paresis acquired in intensive care unit: a prospective multicenter study. JAMA 2002;288:2859-67.

58. Langer D, Gosselink R, Pitta F, et al. Physical activity in daily life 1 year after transplantation. J Heart Lung Transplant 2009;28:572-8.

59. Langer D, Burtin C, Schepers L, et al. Exercise Training After Lung Transplantation Improves Participation in Daily Activity: A Randimized Trial. Am J Transplant 2012;12:1584-92.

60. Gloeckl R, Heinzelmann I, Seeberg S, et al. Effects of complementary whole-body vibration training in patients after lung transplantation: A randomized trial. J Heart Lung Transplant 2015;34:1455-61.

61. Andrianopoulos V, Gloeckl R, Boensch M, et al. Improvements in functional and cognitive status following short-term pulmonary rehabilitation in COPD lung transplant recipients: a pilot study. ERJ Open Res 2019;5:00060-2019. 